\title{
Redefiniendo el videoarte: orígenes, límites y trayectorias de una hibridación en el panorama de la creación audiovisual española contemporánea
}

\section{Redefining Videoart: origins, boundaries and trajectories of a hybridization in the contemporary Spanish audiovisual creation scene}

\author{
Aurelio del Portillo García \\ Profesor Titular (Universidad Rey Juan Carlos) \\ Antonio Caballero Gálvez \\ Investigador (Universidad de Málaga)
}

Fecha de recepción: 9 de abril de 2014

Fecha de revisión: 11 de julio de 2014

Para citar este artículo: del Portillo García, A. y Caballero Gálvez, A. (2014): Redefiniendo el videoarte: orígenes, límites y trayectorias de una hibridación en el panorama de la creación audiovisual española contemporánea., Icono 14, volumen (12), pp. 86-112. doi: 10.7195/ri14.v12i2.707 


\section{Resumen}

La consolidación del videoarte dentro del circuito artístico contemporáneo ha sido un revulsivo tanto para las artes visuales como para el uso tecnológico del vídeo. El paso del vídeo analógico al digital ha supuesto una explosión de formatos y tipologías en el ámbito de la creación audiovisual. Al mismo tiempo, la incorporación de la imagen digital a las pantallas comerciales nos obliga a replantear, dentro de nuestro imaginario cultural, los limites y fronteras impuestos tradicionalmente a la imagen audiovisual, como serían las categorías "cine/vídeo" o "ficción/documental". Realizamos un recorrido retrospectivo sobre los orígenes del vídeo como formato de experimentación creativa hasta su constitución como referente del circuito artístico español. Desde una perspectiva interdisciplinar, tratamos de conocer los elementos y propiedades intrínsecas que convierten al videoarte en un medio de imposible categorización dentro de las estructuras actuales que rigen la cadena de producción audiovisual.

Palabras clave: Videoarte - Cultura Digital - Arte Contemporáneo - Hibridación Imagen en Movimiento - Estudios Visuales

\section{Abstract}

The consolidation of Videoart within the contemporary art scene has been a salutary lesson in the case of both Visual Arts and New Technology. The transition from the analogue world to a digital universe has dealt an explosion of formats and typologies in the specific field of audiovisual creation. At the same time, the incorporation of digital image to the normal screening schedule forces us to reformulate, within our cultural imaginary, the traditional limits and borders imposed on the audiovisual image such as cinema/video or fiction/documentary categories. Our research is a result of a video retrospective overview from its origins as experimental creative medium until its constitution as icon of the Spanish Art scene. From an interdisciplinary perspective, we focus on its intrinsic properties and characteristics that make impossible its categorization within the structures that currently govern the audiovisual production chain.

Key Words: Videoart - Digital Culture - Contemporary Art - Hybridation - Moving Image - Visual Studies

ICONO14 | Año 2014 Volumen 12 N² 2 | ISSN: 1697-8293 | DOI: ri14.v12i2.707 


\section{Introducción}

La historia del videoarte, al igual que la de otras prácticas artísticas como el cine, está llena de anécdotas y leyendas que curiosamente tienden a reducir su origen a uno o muy pocos nombres, sin mostrar que la mayoría de los descubrimientos tecnológicos se deben a un proceso de creación evolutivo en el que intervienen, además de los sujetos, el momento económico, político y sociocultural en el que se desarrollan. Tras casi cincuenta años de historia, todos los intentos para establecer una delimitación cerrada y definitiva del concepto de videoarte, como un medio o disciplina única, con su propia trayectoria, sus propias herramientas de producción, su sistema específico de distribución y su singularidad expositiva, parecen haber fracasado. Partimos, pues, de la evidente dificultad que entraña la categorización del videoarte, tanto en el ámbito de sus propiedades y características, como en el de los medios de realización y explotación sobre los que se sustenta, para intentar aproximarnos a un nuevo enfoque que facilite su comprensión y definición. Y lo hacemos a través de la experiencia de artistas y teóricos relacionados con la creación audiovisual española en el siglo XXI. Es en este entorno histórico en el que consideramos que el arte no puede ya concebirse sin la incorporación del vídeo como un soporte más para la expresión creativa, como lo fueron antaño los lienzos de los pintores.

Para sentar las bases de esta investigación, además de analizar el contexto en el cual surge el videoarte, realizamos una retrospectiva histórica de su evolución como medio y como concepto, para dilucidar las razones por las que aún en pleno siglo XXI se presenta como un medio y/o disciplina tan difícilmente delimitable. Ponemos en relación las diferentes nomenclaturas que el concepto "videoarte" ha ido tomando desde su aparición a finales de los sesenta y principios de los setenta hasta la actualidad, como son "videoarte", "vídeo de creación" e "imagen en movimiento". En pleno desarrollo de la cultura digital, consideramos que es importante aportar una apertura en la concepción del videoarte y proponer desde esa visión una definición no excluyente en la que se marquen líneas definitorias acordes con la naturaleza híbrida del medio y su adaptabilidad a los diferentes espacios y formatos que nacen y crecen en una época marcada por el dominio tecnológico.

DOI: ri14.v12i2.707 | ISSN: 1697-8293 | Año 2014 Volumen 12 N² | ICONO14 
Del mismo modo que para entender la tecnología digital en numerosas ocasiones es necesario conocer los mecanismos analógicos que la preceden, en el caso que nos ocupa consideramos que es imprescindible revisar los distintos formatos y las distintas analogías con las que se ha identificado al videoarte desde la década de los setenta. Por dos motivos fundamentales: en primer lugar, poder entender las conexiones iniciales del videoarte con otras disciplinas audiovisuales, $y$, en segundo lugar, desvincular estas conexiones para poder configurar una definición de videoarte con autonomía propia.

Eugeni Bonet (1980, pp. 10-22) ya había circunscrito el vídeo como un "ismo" dentro de los circuitos artísticos, apuntando además las causas de las contradicciones existentes en la entonces corta historia del videoarte. En primer lugar, lo denominó "cajón de sastre", expresión que posteriormente tomarán numerosos teóricos, críticos e investigadores para ensayar nuevas definiciones, donde se incluye una amalgama de obras y piezas artísticas que solo tienen en común el soporte que han utilizado en su creación. En segundo lugar, Bonet señala directamente a los artistas como responsables de esta confusión y banalización del medio, ya que muchos de ellos utilizaron el vídeo en estos primeros años simplemente por considerarlo una tendencia al alza y no por los efectos e implicaciones que su uso ya conllevaba. Y, por último, apunta al mercantilismo de los museos que impone la edición seriada de las obras para su entrada en el mercado del arte.

Esta descripción crítica de la situación del medio en sus primeros estadios de producción en el Estado Español no varía demasiado con el escenario actual. Pero lo que sí difiere es la interpretación de cada uno de los puntos señalados por Bonet, ya que cada una de las condiciones que rodeaban al videoarte a finales de los sesenta y comienzos de los setenta, que dificultaban su definición y la reivindicación de sus especificidad, se convierten en la primera década del siglo XXI en las condiciones que lo han erigido como una de las disciplinas artísticas de mayor relevancia en el panorama artístico internacional. De ahí el interés de actualizar nuevamente las características y elementos definitorios del videoarte contemporáneo.

En la línea de lo descrito por Bonet, Manuel Palacio, en el catálogo de la que será la primera gran exposición en nuestro país dedicada al vídeo: La imagen sublime, vídeo de creación en España: 1970-1987, señalaba que la dificultad para

ICONO14 | Año 2014 Volumen 12 N² 2 | ISSN: 1697-8293 | DOI: ri14.v12i2.707 
delimitar el campo o territorio del videoarte procedía del "poliformismo" en los usos del soporte videográfico: “La denominación de vídeo de creación (o videoarte) engloba trabajos difícilmente compatibles que solo de una manera muy laxa pueden incluirse en el mismo territorio" (Palacio, 1987, p. 35). En el mismo texto denunciaba abiertamente las razones por las que no se podía crear un marco restrictivo en el ámbito del videoarte: por una parte, la incapacidad del vídeo para establecer su propio espacio de acción significa, según sus palabras, "la carencia de mayor repercusión para la delimitación de su territorio y de una estética independiente" (p. 34); y, por otra parte, al igual que comentaba Bonet, Palacio de nuevo interpela a la relación entre arte y vídeo, ya que en la evolución del vídeo como disciplina artística "se interrelacionan las evoluciones lingüísticas y económicas del arte contemporáneo" (p. 34), lo que nos conduce a pensar y a determinar una relación "dependiente" del vídeo con respecto a la evolución y a los intereses del arte contemporáneo, al igual que ocurre con el resto de disciplinas artísticas dentro de la vorágine mercantilista del capitalismo tardío.

Como comenta Albert Alcoz, es difícil delimitar el campo del videoarte en el Estado Español, no por su representación e influencia, mucho más marcada que la del propio cine experimental -gracias, como él mismo reconoce, al apoyo de las instituciones, centros y museos de arte contemporáneo y a las múltiples muestras dedicadas al videoarte en nuestro país desde la década de los ochenta-, sino "por la falta de criterio en la defensa del vídeo por el vídeo" (Alcoz, 2008, p. 12). Siguiendo esta premisa, junto con el proceso de transición de autores que procedían de una escena marginal de circuitos alternativos hacia un escenario institucionalizado dentro de la esfera del arte contemporáneo, donde surgió el videoarte, asistimos a una fusión creativa que ha propiciado la mutación e hibridación de numerosas obras audiovisuales. Estas creaciones podrían encuadrarse a la vez -en la lógica de las numerosas categorías cinematográficas-, en el cine documental, cine-ensayo, corto de ficción, incluso videoclip, vídeo de animación, y en un sin fin de campos y géneros, complementarios o contradictorios, en los que se desarrolla nuestra cultura visual contemporánea.

Prestamos especial atención a esta hibridación y mutación entre géneros y recursos expresivos, que no ha dejado de evolucionar hasta nuestros días, como uno

DOI: ri14.v12i2.707 | ISSN: 1697-8293 | Año 2014 Volumen 12 N² | ICONO14 
de los soportes fundamentales de nuestra argumentación acerca de la creación videográfica, del llamado "videoarte". Y lo hacemos sin descuidar la relación e interacción con el contexto político, económico y social en el que se ha desenvuelto. Atendemos también de forma muy especial a los ámbitos, espacios y canales que han facilitado, y condicionado, su exhibición y difusión. Y, por supuesto, observando hasta qué punto su razón de ser y su evolución están marcadas por las propias características y actualizaciones de las tecnologías audiovisuales y por el constante diálogo, quizás discusión, con otros medios como son la cinematografía y la televisión.

La imagen videográfica, a diferencia de la imagen cinematográfica, no está compuesta de fotogramas, de imágenes fijas y completas, sino que es una imagen que, al igual que la misma definición del videoarte, está en constante formación. Tal y como comentó en su día Santos Zunzunegui, “la imagen vídeo no existe en el espacio, sino solamente en el tiempo" (1987, p. 58). Retrocedemos a través de textos, obras y exposiciones hasta comprender las razones que han favorecido la constante indefinición del videoarte para situamos con mayor nitidez en el "píxel" en el que se encuentra la creación, producción y distribución del videoarte español hoy, ya a mediados de la segunda década del siglo XXI. En ese recorrido reflexionamos sobre una posible nueva manera de enfrentarnos a este concepto.

\section{Metodología}

Hemos necesitado plantearnos una cierta apertura en la metodología que nos permitiera abarcar nuestro trabajo desde una perspectiva interdisciplinar. Para Della Porta y Keating (2008, pp. 25-26), “aunque aparentemente la cuestión metodológica parezca algo independiente de las discusiones epistemológicas y ontológicas, dado que existen múltiples formas de adquirir conocimiento, en la práctica tienden a estar ligadas, ya que las perspectivas más positivistas en las Ciencias Sociales tienden a utilizar métodos más rígidos, mientras en enfoques más interpretativos suelen utilizar métodos más flexibles (permitiendo cierta ambigüedad y contingencia, reconociendo la interacción entre el investigador y el objeto de estudio".

Las complejidades actuales de la cultura visual requieren, a nuestro juicio, mé-

ICONO14 | Año 2014 Volumen 12 N² 2 | ISSN: 1697-8293 | DOI: ri14.v12i2.707 
todos flexibles que conduzcan a un ámbito de investigación más dinámico, abierto a nuevas áreas y disciplinas de estudio. Tanto el 'giro visual' en las Ciencias Sociales, así como los discursos postmoderno, postestructural y postcolonial, han tenido un impacto directo sobre la forma en la que abordar la investigación de la imagen y de los medios audiovisuales. A partir de esta apertura metodológica, nos hemos basado, por una parte, en los paradigmas marcados por la Hermenéutica de las Imágenes $\mathrm{y}$, por otra, en la interdisciplinariedad de los Estudios Visuales. La Hermenéutica de las Imágenes nos permite recuperar el pensamiento de las imágenes y el estudio de la significación icónica en su relación con la subjetividad y con el mundo histórico que le da vida y sentido. Tal y como señala Lizarazo Arias, “los ámbitos hermenéuticos ofrecen un nuevo escenario para pensar el mundo de la imagen, donde no solo nos interesan las estructuras, sino los movimientos humanos y sociales que dichas formas icónicas cristalizan y ponen en juego" (2004, p. 23).

Del mismo modo que se implementaron las herramientas y métodos de análisis necesarios para el estudio de los denominados "actos de habla" -en su vertiente oral y escrita-, es igualmente necesario crear unos instrumentos útiles y rigurosos para el análisis de los "actos de ver". Considerar que son suficientes los métodos consolidados o adaptar los ya existentes constituiría un "pecado de lesa responsabilidad epistémico-crítica. Y política, si tenemos en cuenta la decisiva importancia que de cara a la conformación del espacio social contemporáneo tienen las imágenes y los 'actos de ver'"' (Brea, 2010, p. 116).

Dentro del campo de los Estudios Visuales, son muchas y diversas las metodologías propuestas para el análisis visual, no textual, de la imagen. Keith Moxey (2009, pp. 7-27) nos da algunas de las claves para entender cuáles son los campos metodológicos que está atravesando la cultura visual, entendida como el objeto de estudio de los estudios visuales, en su búsqueda de un método de análisis propio que nos permita conocerla desde cualquiera de las perspectivas que nos ofrece. Para Moxey, mientras las teorías o ciencias reconocidas académicamente como la antropología visual o teoría fílmica se apoyan en teorías tradicionales basadas en la objetividad y la imparcialidad, así como en las influencias culturales e históricas en la recepción de las imágenes, los estudios visuales relativizan

DOI: ri14.v12i2.707 | ISSN: 1697-8293 | Año 2014 Volumen 12 N² | ICONO14 
sus análisis mediante la posición subjetiva del receptor, y se centran en la función social y política del objeto de estudio. "Mucho depende de si el concepto de imagen es considerado un "lugar de sustento", una construcción cultural que está llena de significado adscrito a las circunstancias en las que se produce y recibe, o si es venerado como potencialmente cargado con presencia icónica" (Moxey, 2009, p. 10).

Nicholas Mirzoeff (2003) concibe como objeto de análisis de los estudios visuales el mensaje intrínseco de las imágenes, del videoarte en nuestro caso, más que el propio medio, centrando el análisis en las funciones culturales y los mecanismos políticos de las imágenes en su presentación pública. De forma más amplia, W. J. T. Mitchell hace un llamamiento a los analistas para que presten especial atención a los mecanismos de funcionamiento de la percepción de la imagen en el espectador. Mitchell está interesado tanto en la función ontológica como en la proyección política de la imagen. “El valor de las imágenes consiste en poner de manifiesto que los interrogantes que se formulen en torno a las imágenes no deben ser del tipo de ¿qué significa? o ¿qué hacen?, sino, más bien, de ¿cuál es el secreto de su vitalidad? y ¿qué quieren?" (Mitchell, 2003, p. 35).

Nuestro esquema de trabajo parte en primer lugar de una revisión retrospectiva sobre las distintas definiciones y nomenclaturas que ha recibido el videoarte desde sus comienzos en España. Y, en segundo lugar, de una puesta en común del concepto "videoarte" a través del diálogo y conexión de este medio con el resto de los medios audiovisuales de los que se nutre, y a los que nutre, como son la televisión, el cine experimental y el vídeo digital. Por último, basándonos en el trabajo de investigación La representación de las masculinidad(es) en el videoarte español [2000-2010] (Caballero, 2012), aplicamos al estudio el análisis de la problemática de su categorización desde la perspectiva del soporte, la narratividad y el marco espacial -institución, centro de arte, galería, museo- donde la pieza se efectúa y toma forma como discurso, reflexionando sobre los efectos que estos vídeos producen en los espacios artísticos donde se insertan.

ICONO14 | Año 2014 Volumen 12 Nº 2 | ISSN: 1697-8293 | DOI: ri14.v12i2.707 


\section{Resultados}

Las diferentes nomenclaturas que el concepto videoarte ha ido tomando a lo largo de sus más de cincuenta años de historia no han ayudado mucho para poder concretar una definición. En los años setenta, aunque con diferentes enfoques, toda actitud artística en el uso del vídeo se denominó "videoarte". Posteriormente pasó a llamarse "vídeo de creación" en la multitud de festivales que se desarrollaron durante los ochenta, hasta la llegada de los noventa con el uso de la "imagen en movimiento", denominación ligada a las bienales que determinaron su nombre: I Bienal de la imagen en movimiento (1990) y II Bienal de la imagen en movimiento. Visionarios españoles (1992). Sin embargo, con la entrada del nuevo siglo, y especialmente tras esta primera década, en línea con lo señalado por Amber Gibson (2010), todas las etiquetas han dejado de tener sentido, y se ha retomado el término originario "videoarte" de los setenta, pero esta vez desde una posición mucho más híbrida y, a su vez, constructiva. En esta nueva concepción, tal y como entiende Gibson, y como ahora defendemos, las variables para su delimitación no se encuentran en el soporte fílmico y/o videográfico, sino que dependerían del contexto donde se producen y exhiben.

La definición del videoarte sigue en construcción, tal y como fue en sus inicios. Por una parte, hay una línea crítica de opinión que considera el soporte o medio tecnológico como característica fundamental en su acotación, como es el caso de las comisarias Blanca de la Torre e Inma Prieto (2011, p. 11), quienes toman el soporte de grabación como premisa a cumplir por las obras seleccionadas para la exposición, admitiendo su reduccionismo. Sin embargo, Amber Gibson (2010, p. 20) defiende la libertad e indefinición del término, con la siguiente observación: “Hoy en día se habla de filmar cuando se graba en vídeo digital, y por el contrario, se describen obras como vídeos cuando son en esencia fílmicas en su escala e intención [...] La realidad de nuestro presente es que tales distinciones se han vuelto irrelevantes". Actualmente, la definición de videoarte no se rige por la materialidad o los medios tecnológicos de producción sino por su estética formal y el contexto donde son presentados. Por lo tanto, nos encontramos con producciones cinematográficas que son piezas de videoarte y otras que son lo que tradicionalmente conocemos como cine, así como con producciones videográficas que son videoarte

DOI: ri14.v12i2.707 | ISSN: 1697-8293 | Año 2014 Volumen 12 N² 2 | ICONO14 
y otras que son televisión o forman parte de un archivo videográfico. Además, consideramos que uno de los criterios más relevantes en la valoración de las piezas como videoarte sería la intencionalidad del artista durante su realización.

La supuesta limitación que supone no pertenecer a una categoría propia ha permitido al videoarte en esta primera década del siglo XXI adquirir una definición mucho más amplia, rica, abierta y flexible gracias a la asimilación de su naturaleza híbrida y la aceptación de todas sus fisuras como espacios de penetración de otras disciplinas y herramientas audiovisuales. Tal y como apuntó Berta Sichel en el catálogo de la exposición Monocanal, el videoarte "ha dejado atrás y para siempre los márgenes para ocupar el centro de la creación artística contemporánea" (2003, p. 13).

Precisar la naturaleza, especificidad y márgenes limítrofes del videoarte es una tarea que conlleva importantes dificultades en el ámbito de la teoría videográfica y de la puesta en práctica de todo su potencial expresivo. Aunque el videoarte trata de buscar su propio territorio de creación, discusión y reflexión, es precisamente en esa ausencia de espacio propio donde se encuentra su contemporaneidad como relato audiovisual posmoderno. Esto nos conduce a lo que José Luis Brea ha llamado la "i-limitación del arte" dentro de la era "post-crítica": 'I-limitar' el arte, en suma, es abrirlo a una positividad incontestable, no graduada por ningún tipo de comparación o jerarquía que pudiera comprimirla en la 'tensión critica' de su integridad territorial" (Brea, 2000, p. 96).

La adaptabilidad del vídeo a las nuevas tecnologías ha evitado su caducidad o estancamiento. El videoarte se ha nutrido del cine experimental, de la televisión y de Internet, tanto desde un punto de vista creativo como tecnológico. La adaptación a la Red ha implicado su digitalización, con los respectivos beneficios, en el más amplio sentido del término, que este hecho ha supuesto. La permeabilidad del vídeo le ha permitido dialogar con otros lenguajes artísticos como la pintura, la escultura, la danza o la performance, lo que ha dado lugar a híbridos como la "vídeo-escultura", "vídeo-danza" o "vídeo-performance". Su relación con el campo audiovisual ha permitido el desarrollo de importantes formatos híbridos consolidados como son el videoclip o los videojuegos. Estas hibridaciones surgen de la mis-

ICONO14 | Año 2014 Volumen 12 N² | ISSN: 1697-8293 | DOI: ri14.v12i2.707 
ma esencia de la época en la que se han desarrollado, ya que la 'intertextualidad' es una de las características principales de la cultura contemporánea, tal y como apuntó Umberto Eco en Apocalípticos e Integrados (2004 [1965]).

La entrada del videoarte en los museos ha supuesto la adaptación de la economía de la industria del arte alrededor del "mercado audiovisual". En este ámbito, la singularidad de la obra ha desaparecido con su reproductibilidad, tal y como ya apuntaba José Luis Brea en "La obra de arte y el fin de la era de lo singular", texto incluido en el catálogo de la exposición Monocanal (2003). Aunque cada uno de estos condicionantes son razonablemente criticados y puestos en cuestión, cabe considerar que tanto la "descategorización" del medio y su flexibilidad, el uso multidisciplinar del vídeo por parte de los artistas, aunque con mayor conocimiento y conciencia en la actualidad, así como, por supuesto, la entrada en las colecciones de arte de las piezas seriadas de los videoartistas, han sido determinantes en la supervivencia y consolidación del videoarte.

Además de las fisuras que ya presentaba el vídeo desde sus orígenes, tal y como ya señalaron Eugeni Bonet (1980) y Manuel Palacio (1987), en la actualidad estas aperturas por las que el videoarte se relaciona con otros medios y disciplinas no se han cerrado, sino que se han vuelto mucho más penetrables. Así lo predice Ivonne Spielmann (2008), quien considera que la transición de lo analógico a lo digital en el vídeo no ha sido un simple paso intermedio, sino que ha puesto de manifiesto su gran potencial con respecto a la interactividad, complejidad e hibridación en el futuro del vídeo como medio.

No podemos dejar de observar aquí también algunos contextos sociales de enorme importancia en los orígenes y primeros estadios de desarrollo del vídeo como herramienta de expresión en una relación muy cercana con los albores del medio televisivo, mucho más que una 'fisura' en la relación del videoarte con otros medios. El arte de los sesenta y los setenta comenzó a fijarse ya en las tecnologías de la comunicación, pero sobre todo fueron los grandes movimientos en apoyo de los derechos humanos los que lo definieron. El movimiento Guerrilla TV, junto con otros trabajos de vídeo - activismo y de reivindicación social, marcaron el inicio de las que serían las primeras exposiciones de videoarte a mediados de los sesenta,

DOI: ri14.v12i2.707 | ISSN: 1697-8293 | Año 2014 Volumen 12 №2 | ICONO14 
inauguradas por Paik, Vostell y Dan Graham, entre otros. La evolución de la televisión y del vídeo está ahora en una etapa crucial en este sentido. Ante los condicionantes económicos y políticos que conducen al control ideológico y estratégico de los canales de televisión, crece la utilización del vídeo en canales alternativos. El más importante, a buen seguro, es Internet. Pero también se reproducen exposiciones y actos publicos sobre temas sociales en los que la creación videográfica independiente cobra un nuevo valor y sentido. No podemos prufundizar aquí en este apasionante conflicto, por lo que nos limitamos a apuntarlo como un espacio más de interacción entre dos medios hermanos, aunque no siempre bien avenidos.

Las sinergias entre el vídeo, la televisión y los espacios de exhibición han dado muestras interdisciplinarias muy positivas, como fue la memorable y reconocida experiencia expositiva y televisiva: Good morning, Mr. Orwell, de Nam June Paik, el primer programa emitido internacionalmente vía satélite, producido por la cadena de televisión WNET y el Centre George Pompidou (París), como homenaje a 1984, la distopía de George Orwell, con piezas de Laurie Anderson, John Cage, Merce Cunningham o Joseph Beuys, entre otros artistas.

Actualmente, podemos confirmar que la diglosia entre arte y televisión ha desaparecido. La clave o esencia de las obras vuelve a ser la propia creación artística centrada tanto en la propia reflexión introspectiva del artista como en la actitud rupturista con las estéticas destinadas a construir un discurso audiovisual alienado. Aunque no siempre ha sido así, ya que, como nos recuerda Eugeni Bonet, "el vídeo adopta inicialmente un planteamiento antagonista: 'anti' o contra la televisión. [...] coincide en el tiempo con el antiarte y anticine de Fluxus y otros movimientos o grupos: el letrismo, los situacionistas, el pop art,..." (2009, p. 61), y a su vez reconoce que una década más tarde, en los ochenta, "el 'anti' se volverá 'pro'. Se habla de 'posvideoarte' y los géneros o formatos de la televisión y el cine, además del videoclip, son adoptados sin ambages" (2009, p. 61).

A partir del año 2010 surgen una serie de voces en torno a la "otra" televisión que devuelven a la actualidad este debate. Esta vez no surgen desde un ámbito alternativo o underground sino desde los mismos centros de arte institucionalizados: Museu d'Art Contemporani de Barcelona: ¿Estáis listos para la televisión? (2010);

ICONO14 | Año 2014 Volumen 12 N² 2 | ISSN: 1697-8293 | DOI: ri14.v12i2.707 
Centro Arts Santa Mónica (Barcelona): TV/ARTS/TV (2010); así como el ciclo en La Casa Encendida (Madrid): Otra televisión es posible (2010) y otras jornadas, de menor duración, en Artium (Vitoria-Gasteiz): ¿De qué nos hablan cuándo dicen esa "otra" televisión? (2010).

El diálogo entre el arte y la televisión siempre ha sido un cuestión controvertida, especialmente por el trato "despectivo" que la industria del arte -"alta cultura"- siempre le ha dado al medio de masas: la televisión -“baja cultura"- tal y como pusieron de manifiesto los críticos Marcelo Expósito y Gabriel Villota (1993). Para ellos el videoarte no entra dentro del paradigma de la televisión. Ya para el "videoartista" afín a la visión del artista genial, siguiendo el modelo estético kantiano, resulta imposible compatibilizar sus intereses románticos con los objetivos comerciales de la televisión de masas. Aún con intereses distintos, el encuentro del arte con la televisión fue inevitable y de este encuentro surge el videoarte como uno de sus más importantes reflejos. Una de las publicaciones que mejor recoge la existencia de esta "otra televisión" ha sido La televisión no lo filma, a cargo del colectivo sevillano Zemos 98. En esta publicación se recogen las palabras del artista y crítico Fran Ilich, creador de los proyectos delete.tv y Posible Words, quien considera que "otra televisión es posible si pensamos en algo que no sea televisión" (Zemos 98, 2006, p. 122).

Estamos de acuerdo con las palabras de Berta Sichel cuando reconoce que "la televisión solo de forma puntual retransmitió -y retransmite- producciones procedentes de las prácticas artísticas. La televisión nunca fue una opción preferente para la difusión y promoción del videoarte" (Sichel, 2003, p. 19). Aún así, debemos admitir que esta inevitable relación ha ido evolucionando desde una actitud reaccionaria en los setenta, tanto por parte del vídeo como por parte de la televisión, hacia una mucho más accesible e integradora en la década de los ochenta, tal y como muestran algunos ejemplos en las televisiones del Estado Español -especialmente las retransmisiones de las dos ediciones del Festival de Vídeo Internacional de San Sebastián (1982 y 1983) y, especialmente, la aparición del programa de TVE Metrópolis en 1985 (actualmente continúa en antena), hasta su completa disgregación en los noventa y especialmente en el siglo XXI.

DOI: ri14.v12i2.707 | ISSN: 1697-8293 | Año 2014 Volumen 12 № 2 | ICONO14 
Si tomamos en sentido literal esta sentencia: "la gran tragedia del vídeo como "lenguaje" es que nace con un retraso de veinte años respecto a la televisión, cuando ésta se ha convertido en el más importante medio de comunicación que ha conocido la humanidad" (Palacio, 1987, p. 40), no encontramos calificativos para nombrar la distancia temporal entre el vídeo y su otro gran "contendiente", el cine, o, más concretamente, el cine experimental, si pensamos en las primeras películas de Diga Vertov, Germaine Dulac, Fernand Lèger, Maya Deren o Stan Brackage. Sin embargo, no consideramos que este "retraso" haya supuesto una "tragedia" sino todo lo contrario, ya que tanto la televisión como el cine experimental han sido determinantes para la aparición y desarrollo del videoarte. Además, consideramos que ha sido desde una actitud de aceptación, y no de rechazo, desde donde el videoarte ha podido asentar las bases de su propio lenguaje propio. De nuevo observamos algunos excesos en la obsesiva intención de fragmentar y distinguir característica de nuestra época, en este caso en la innecesaria delimitación radical entre cine y vídeo. "Hoy la terminología que había separado los conceptos de cineasta y artista o de película y de pieza, carece de sentido" (Quintana, 2011, p. 64). Dentro de los estudios visuales contemporáneos no se puede separar drásticamente el vídeo de las prácticas fílmicas y artísticas.

El tiempo, y todo lo que éste implica en ambas prácticas, sería el principal nexo o frontera por la cual tanto se unen como se diferencian el videoarte y el cine experimental. Ambas prácticas comparten su naturaleza y esencia espacio-temporal y ambas, desde sus orígenes hasta la actualidad, continúan profundizando e investigando en el uso del tiempo como material plástico-expresivo. Mientras en la mayoría de los trabajos de cine experimental se persigue una contracción del tiempo, el videoarte, en la búsqueda de una nueva tendencia, intenta jugar más con la aproximación del tiempo de grabación al tiempo 'real'. Incluso puede abrir nuevas dimensiones temporales al interactuar con el espectador en los espacios de representación.

La entrada de la imagen en movimiento dentro de los museos fue a través de los trabajos cinematográficos de Andy Warhol, Jonas Mekas, Chris Marker y otros artistas de cine experimental, ya que en el origen del cine experimental está su naturaleza artística, algo que difiere del surgimiento del videoarte (Quintana,

ICONO14 | Año 2014 Volumen 12 Nº 2 | ISSN: 1697-8293 | DOI: ri14.v12i2.707 
2011, pp. 67-68). El origen técnico del vídeo surge desde tres focos: el primero, los trabajos sonoros de la música experimental y del vídeo -el caso de John Cage y Nam June Paik-; el segundo, el desarrollo del vídeo dentro de la TV -como sería el movimiento Fluxus o el español Antoni Muntadas-; y el tercero, desde el campo de la performance -Vito Acconci, Marina Abramovic \& Ulay, entre otros-. Consideramos que esta controversia no es tan visible al tratar de videoperforman$c e$, videoesculturas o videoinstalaciones, donde el visitante se desplaza buscando integrar en el espacio su visión fragmentada, sino que se materializa especialmente en el momento en el que dentro de un museo -"caja blanca"- asistimos a una proyección dentro de la "caja negra" -simulación de la sala de exhibición cinematográfica tradicional-, donde la pieza impone una duración determinada que limita la libertad del espectador, al igual que sucede en la proyección de una película. Y es en este punto donde la línea diferencial entre cine, documental, cine experimental, animación o videoarte es prácticamente invisible. Este desplazamiento del cine experimental de la sala comercial -“caja negra"- hacia el museo -"caja blanca"- es lo que conduce a la creciente incertidumbre en su territorialización.

En esta tierra de nadie, o espacio híbrido, es precisamente donde se insertan nuevas concepciones del medio, como serían el "cine expositivo" o el "vídeo en pantalla", cuyo máximo exponente son las obras de Douglas Gordon dedicadas a la filmografía de Alfred Hitchcock (destacamos como ejemplo 24 Hours Psycho, de 1993). De estas fuentes se nutren los creadores videográficos, como también de las artes plásticas, del teatro o de la música. Del arte en general. Aunque quizás "con los videoartistas descubrimos que, por primera vez, quizás no estén estudiando la historia del arte, sino la historia del cine" (Torrente, 2009, p. 9). El trabajo de las artistas Cabello/Carceller sería el mayor exponente de este hecho dentro del panorama videoartístico español, especialmente si pensamos en sus diálogos con algunos filmes históricos: Rebelde sin causa (Nicholas Ray, 1955) en su obra de vídeo Casting: James Dean (Rebelde sin causa) (1994); Apocalipsis Now (Francis Ford Coppola, 1979) en la pieza de vídeo After Apocalypse Now: Martin Sheen (The Soldier) (2007); o su más reciente homenaje a Blow Up (Michelangelo Antonioni, 1966) a través del vídeo A/O Caso Céspedes (2010).

DOI: ri14.v12i2.707 | ISSN: 1697-8293 | Año 2014 Volumen 12 № 2 | ICONO14 
Nam June Paik y Jean-Luc Godard serían los grandes representantes de cada una de estas disciplinas: el primero en el ámbito del vídeo y el segundo en el del cine. Pero, tal y como hemos apuntado al inicio de este apartado, no tienen por qué ser incompatibles, mucho menos en una época en la que el soporte digital se ha encargado de expandir todas sus capacidades tecnológicas hasta disolver las fronteras entre ambios medios. En el campo de la creación, muchos nombres del ámbito cinematográfico han apostado por el ámbito expositivo, como puede ser el caso de Steve McQueen o Tsai Ming Liang, o en nuestro país el caso de Isaki Lacuesta o Andrés Duque. Del mismo modo, también muchas figuras del panorama del arte contemporáneo se han lanzado al cine, como podrían ser los casos de Douglas Gordon, Elija Liisa Athila, Matthew Barney o Isaac Julien, o el salto de Martín Sastre de las salas de arte al gran circuito de las salas de exhibición cinematográficas con su filme Miss Quatarembó (2010).

En este momento, en el que ya no existen fronteras claras, es donde se hallan las nuevas vías de futuro del videoarte contemporáneo. Este nuevo panorama ha generado "un retorno al cine primitivo. La creación contemporánea abraza los orígenes, cuando los conceptos de narratividad no existían y la experimentación buscaba nuevas formas de atracción o percepción" (Quintana, 2011, p. 73). Esta vuelta a los orígenes nos hace recordar que, en poco más de cien años, el cine ha pasado de las barracas de feria a los museos, galerías y colecciones más importantes del mundo, algo que siempre debemos tener en cuenta a la hora de estudiar la evolución de la "imagen en movimiento".

La llegada de la cámara digital, acompañada por todo el equipamiento necesario para la producción, montaje y visualización de imágenes en movimiento, ha modificado de manera irremisible la estética audiovisual. La base de este cambio estético es que el plano ya no es la unidad básica para la configuración del espacio tiempo, sino el píxel. El artista puede modificar las escalas de los objetos, puede mezclar en el mismo cuadro de representación espacios y tiempos diversos gracias a la transición de imágenes, incrustaciones, sobreimpresiones, etcétera. La nueva tecnología digital permite reordenar fragmentos y multiplicar la virtualidad del procedimiento con las posibilidades del montaje digital. “El artista se agencia la capacidad de dotar a la imagen producida de un sentido alegórico, capaz de revelar

ICONO14 | Año 2014 Volumen 12 N² | ISSN: 1697-8293 | DOI: ri14.v12i2.707 
un orden de relaciones entre las cosas que subvierte y resiste al orden de la representación. El propio Jacques Derrida ha insistido en la relevancia del aporte de las altas tecnologías de cara a este ejercicio deconstructivo en el campo de las artes visuales" (Brea, 2000, p. 244).

La digitalización del universo audiovisual ha modificado todo el engranaje de la industria del arte, de las telecomunicaciones y, como no, de la cinematografía. El uso de la cámara digital en sus diversos formatos $-H D$, Full $H D$, $3 D$ - se ha extendido en la producción cinematográfica, primordialmente por el abaratamiento en la cadena de realización, producción, distribución y exhibición, así como también por el cambio estético de este siglo XXI, tan imbricado con la cibernética. De ahí que algunas voces hayan acuñado el término "cinematización" del vídeo (Rush, 2011, p. 175).

La inmaterialidad del videoarte se ha acrecentado con su digitalización. Cuando José Luis Brea (2005) reflexiona sobre el "fin de la obra singular" está haciendo referencia a la transgresión que supondría el hecho en sí de la reproducción digital sin límites de la obra audiovisual sobre las relaciones del mercado, el coleccionismo y otras estructuras arraigadas en el sistema capitalista del arte. Esto implicaría, por una parte, un nuevo paradigma en cuanto a la relación del espectador y la obra. Por otra, una vía libre a la circulación de las obras en una economía "post-mercantil", en términos de Brea, quien considera todo esto a la vez factible e inviable, teniendo en cuenta los fuertes intereses de la economía del arte y los controvertidos derechos de exhibición. En esta "post-economía", estigmatizada por la utopía, del mismo modo que desaparece la singularidad del artista-genio, también desaparece ese destinatario-individuo / sujeto-individuo, en concordancia con la idea de sujeto como multiplicidad defendida por Brea. Existen algunos sectores de la cadena del mercado del arte que se resisten, o incluso se oponen, a aceptar los cambios impuestos por el uso generalizado de la tecnología digital, dada su capacidad revolucionaria a la hora de crear, reproducir y distribuir fuera de las bases económicas convencionales que rigen el mundo del arte contemporáneo. “La realidad ha sido expulsada de la realidad. Solo la tecnología sigue tal vez uniendo los fragmentos dispersos de lo real" (Baudrillard, 1996, p. 7).

DOI: ri14.v12i2.707 | ISSN: 1697-8293 | Año 2014 Volumen 12 № 2 | ICONO14 
En este marco de fronteras imprecisas, si bien encontramos los inicios de un futuro prometedor, nos toparemos siempre con evidentes complicaciones a la hora de categorizar nuestro objeto de estudio. Si lo intentamos basándonos en la distinción del soporte, nos arriesgamos a establecer una clasificación, considerada por Blanca de la Torre e Inma Prieto como "reduccionista" (2011, p. 3), ya que es una de las variables más castradoras, en cuanto no distingue diferentes categorías dentro del videoarte sino que separa de forma irreconciliable lo que es videoarte de lo que no es:

- Videoarte: cualquier pieza de vídeo realizada en un soporte magnético. Aunque esta definición, según la muestra seleccionada en Video(S)torias, se ha ampliado al soporte digital.

- No Videoarte: donde localizamos las piezas realizadas en celuloide $-8 \mathrm{~mm}$ / $16 \mathrm{~mm}$ - 0 en el tradicional, aunque últimamente recuperado, super $8, \mathrm{y}$, por otra parte, las categorías surgidas por la influencia de las nuevas tecnologías e Internet, como son el videojuego, la animación, art.net, y el resto de formatos derivados de la "cibernética".

Si tenemos en cuenta la variable de la narratividad, y nos atenemos a la dualidad artificiosa entre ficción y documental -donde incluimos todos los trabajos de no-ficción-, es muy probable que descuidemos muchos matices importantes. Según la categorización realizada por Eugeni Bonet en el catálogo de La Imagen Sublime (1987), en las primeras clasificaciones de los años setenta se distinguían tres áreas básicas dentro del campo de creación videográfica de la época:

- Vídeo documental y/o de contrainformación: donde podemos incluir todos los trabajos de Guerrilla TV o, en el caso de España, Video-Nou o Servei de Video Comunitari.

- Vídeo de experimentación electrónica: al que pertenecen las obras de Nam June Paik y W. Vostell, entre otros muchos artistas que trabajaron en el campo de la experimentación con la materialidad y los elementos electrónicos y magnéticos que componían la señal de vídeo. 
- Vídeo conceptual o videoperformance: donde se insertan la mayoría de los trabajos, encabezados por las obras de Merce Cunningham -procedente de la danza- y Vito Acconti -procedente del 'happenning' y la 'performance'-.

Además de estos subgrupos nos gustaría señalar un área clave en los inicios y evolución del videoarte, como sería el "Vídeo de reflexión - crítica de la TV", un tipo de videoarte que posteriormente no ha tenido una continuidad en artistas de generaciones posteriores, aunque actualmente aparecen algunos trabajos aislados en la línea de la ya señalada "otra televisión". A finales de la década de los ochenta, todas estas "clases" de vídeo se reducen a la distinción entre ficción o documental, una separación que perdura hasta nuestros días. La diferencia con la actualidad es que ambos, la ficción $\mathrm{y}$, especialmente, el documental, se insertan en ese ya denostado "cajón de sastre" que comentábamos antes, adjudicado al videoarte ante la evidente dificultad de establecer clasificaciones más precisas. Los desplazamientos entre el documental y la ficción son una constante en una época perturbada por la exhibición de lo "real", ya que no se trata "de hacer explotar lo real en el interior mismo de la ficción, sino más bien hacer que la ficción surja de lo real mismo" (Quintana, 2008, p. 103).

La clasificación según el espacio se ha inscrito dentro de criterios que podríamos considerar morfológicos respecto a la apariencia más externa -visual- de la obra: la ocupación de un determinado espacio físico -el espacio de visionado-. La entrada del videoarte en el denominado "cubo blanco" no fue fácil, y su exhibición ha ido evolucionando según la tendencia de las prácticas curatoriales o los criterios personales del propio artista. Desde sus inicios hasta la actualidad podríamos señalar que el videoarte ha pasado de seguir los patrones marcados por la proyección cinematográfica, es decir, en una estructura oscura -"caja negra"-, pero dentro del museo, hasta posicionarse en el mismo espacio ocupado por el resto de las artes, a modo de "marco pictórico". Su expansión en este último decenio lo sitúa monitorizado en grandes o pequeñas pantallas -LCD, Plasma, LED- o proyectado, ya sea dentro de la sala oscura o en las propias paredes interiores del museo o en la fachada exterior de la "caja blanca", aludiendo a la obra de Pipilotti Rist proyectada en la plaza del Pompidou en París o la pieza de Daniel Canogar dentro del patio de la sede del Consejo de la UE.

DOI: ri14.v12i2.707 | ISSN: 1697-8293 | Año 2014 Volumen 12 №2 | ICONO14 
Algunas categorías se han determinado teniendo en cuenta su disposición espacial, sus formas de visionado y su proyección (Martín, 2006):

- Proyección monocanal: es una forma de producción de vídeo concebida para ser proyectada en un monitor o en una pantalla única. La recepción de obras en monocanal establece un tipo de relación bipolar similar a la creada en el teatro, el cine o la tv: la imagen a un lado y el espectador al otro.

- Circuito cerrado: Las imágenes son transmitidas en directo por retroacción, es decir, la cámara y el proyector se encuentran sincronizados. De esta forma se puede jugar con la imagen del espectador, que puede convertirse en la propia imagen de la proyección.

- Vídeo-performance: Habría que distinguir entre "performance", que es la que se realiza en el acto, en el instante, de la cual no pueden quedar huellas una vez acabada, y la videoperformance, en las que la performance se realiza en función de su grabación. El vídeo desmaterializa el cuerpo real y permite al artista aparecer como una imagen, tal y como lo utilizaba Merce Cunningham, quien manipulaba la posición de la cámara y su cuerpo a la hora de auto-registrarse mientras desarrollaba una coreografía. 0 , en el caso español, la mayor parte de la obra de Pedro Garhel, Miguel Benlloch o Joan Morey. Aunque hay autores que atribuyen el uso del vídeo en la performance por necesidades económicas, de comunicación o archivo documental, no consideramos estas piezas como videoperformance, ya que el vídeo no ha participado en el proceso de creación de la obra.

- Vídeo-escultura: El concepto de vídeo escultura fue consagrado a través de la exposición Video Skulptur (1989) en el Kolnischer Kunstverein de Colonia (Alemania), donde se indagaba sobre la utilización de elementos técnicos y conceptuales del vídeo en la creación de objetos y dispositivos de interacción. Para Juan Carlos Esteban de Mercado, autor de la tesis "Vídeo-esculturas y Vídeoinstalaciones en España", una vídeo-escultura es cualquier "escultura que lleve incorporado un aparato de reproducción de imagen electrónica" (Esteban, 2002, p. 31). Este tipo de instalación escultórica también puede ser visto como una

ICONO14 | Año 2014 Volumen 12 NN$^{\circ} 2$ | ISSN: 1697-8293 | DOI: ril4.v12i2.707 
estrategia para hacer que el vídeo encaje dentro de las corrientes del circuito del arte que procuran forzar la materialidad de la imagen de vídeo para crear un "objeto" adecuado que dé respuesta a exigencias puramente mercantiles.

- Vídeo-instalación: Para algunos autores es una de las aportaciones más importantes del vídeo al mundo del arte y al audiovisual, especialmente por descentralizar el punto de vista unidireccional de la obra de arte tradicional y cuestionar la pasividad del espectador al volverlo partícipe y protagonista y permitirle una mayor libertad a la hora de elegir el orden de lectura y duración de las imágenes. El vídeo se convierte en una experiencia subjetiva.

La categorización del videoarte según el espacio de exhibición es también problemática y discutible. En el momento en el que admitimos tales categorías, estamos dejando de lado muchas otras obras que no entran en los límites marcados por ellas. Nombremos, como ejemplo, algunas hibridaciones: vídeos en circuito cerrado que pueden ser monocanal o multicanal, o vídeo-instalaciones que pueden ser en circuito cerrado o estar compuestas por varias vídeo-esculturas, al igual que la videoperformance puede mostrarse en circuito cerrado, y así podríamos seguir haciendo combinaciones entre subgéneros hasta desmontar la posibilidad de definiciones cerradas en cada una de estas categorías. Como nos ha ido sucediendo en todos los intentos de categorización anteriormente observados. Hemos asistido al relato de diferentes enfoques, miradas, criterios, comparaciones, reflexiones, etcétera, a lo largo de una trayectoria histórica relativamente breve, aunque marcada por una aceleración vertiginosa en el ámbito de la evolución tecnológica y de las ventanas de exhibición para productos procedentes de la creatividad audiovisual. Nos planteamos ahora si estas incipientes clasificaciones y revisiones teóricas han servido de algún modo como avance para perfilar correctamente el concepto de videoarte al que nos hemos enfrentado y si podemos, de aquí en adelante, situarnos ante ello desde un punto de vista diferente.

\section{Discusión}

La hibridación y la mutabilidad son inherentes a la naturaleza y esencia del videoarte, lo que, de algún modo, imposibilita su categorización. De hecho, po-

DOI: ri14.v12i2.707 | ISSN: 1697-8293 | Año 2014 Volumen 12 N² | ICONO14 
dríamos iniciar un ejercicio de división de subcategorías dentro de las categorías ya descritas que seguirían subdividiéndose ad infinitum, evidenciando la inestabilidad que caracteriza el restrictivo e insuficiente sistema taxonómico que se ha venido aplicando en las últimas décadas y que consideramos prácticamente invalidado por sus propias contradicciones y limitaciones. Ante esta posible "descategorización" del videoarte debemos tener en cuenta que estamos inmersos en una sociedad en la que todo objeto o sujeto es susceptible de ser categorizado o clasificado, y nuestro objeto de estudio no iba a ser una excepción. Pero, a su vez, debemos ser conscientes de que las categorías no existen por sí mismas, sino que son un sistema expandido de construcción sociocultural, producto y resultado de las relaciones económicas y políticas de las diferentes estructuras de poder. Tomando como base todos los datos y reflexiones anteriores, consideramos que una subdivisión o categorización de géneros videográficos no es intrínseca a la propia naturaleza del vídeo, sino que viene impuesta por otros factores, ya sea desde la crítica o la teoría como también desde la directrices del mercado, tal y como ocurrió en su día con el cine. Las categorías son, en este caso, mecanismos que permiten el control de la producción y de su consiguiente puesta en circulación.

Si queremos evitar cualquier tipo de categorización anquilosada en cuanto a la tipología del videoarte, especialmente en el contexto temporal en el que se desarrolla, caracterizado por la interdisciplinaridad e hibridación de diferentes artes y técnicas, consideramos inevitable y necesario realizar una revisión de las variables que se han manejado hasta ahora para conceptualizar sus géneros. Hemos partido de tres parámetros principales a través de los cuáles se han vertebrado y construido las categorías de la creación videográfica: primero, teniendo en cuenta el espacio de exposición o visionado; segundo, según la narratividad (aquí se incluiría el polémico binomio "ficción / no-ficción"); y tercero, la consideración del soporte empleado en la creación de la obra. A través de la exposición de estas divisiones, se ha pretendido asentar y reforzar el concepto del videoarte, a nuestro juicio de forma muy limitada y sin mucho éxito. Para lo que sí ha servido este ejercicio teórico ha sido para evidenciar la inestabilidad y permeabilidad de las categorías destacadas, sugiriendo e inspirando un claro alejamiento del intento, hasta ahora perseverante, por circunscribir y limitar su campo de acción.

ICONO14 | Año 2014 Volumen 12 N² 2 | ISSN: 1697-8293 | DOI: ri14.v12i2.707 
Si bien nos hemos ceñido a una definición construida sobre la base de las características del videoarte contemporáneo, a través de la puesta en común de diferentes articulaciones teóricas realizadas hasta nuestros días, las definiciones se derrumbarían en el momento en que confrontáramos el videoarte con nuevas concepciones y usos del conocido como arte de los "nuevos medios": arte digital, arte multimedia, arte electrónico, net art y una lista aún sin concluir de nuevas adscripciones. Este listado reforzaría nuestra idea del videoarte como medio de imposible categorización, aunque sin duda estaría incluido entre estos "nuevos medios" como una disciplina más, con características propias que podrían distinguirlo del resto de formatos artísticos digitales y con interesantes e importantes aspectos en común con todos ellos. La hibridación y la mutación continúan. Por ello será importante prestar atención a todos los cambios que se deriven de esa evolución constante para conocer los nuevos ámbitos de actuación y diversificación en los que se moverá el videoarte a lo largo del siglo XXI.

Sí queremos apuntar algunos criterios que podemos manejar a la hora de valorar lo que es o no una pieza de videoarte y que no están determinados por el espacio o dispositivo de representación y visionado, por clasificaciones narrativas, ni por su soporte -fotográfico-fílmico, digital, hipermedia y/o formas híbridas-, sino, por una parte, por el acto de mostrar y, por otra, por la actitud que toma el artista, esa "actitud artística" que valoraba Josu Rekalde (2000), en cuanto a su concepción, distribución y, en última instancia, su exhibición, aspectos que actualmente también se encuentran en un importante proceso de transformación. Tal y como apuntaba José Luis Brea (2003, p. 25), el videoarte debería responder a una nueva economía "post-mercantil" que posibilitara la libre circulación de las obras. Una nueva economía y sistema de mercantilización factible que expandiría las posibilidades de visualización y distribución del videoarte, pero que a día de hoy se sigue entendiendo como una utopía dentro del sistema de galerías y ferias de arte que buscan en la limitación seriada la única vía posible para su rentabilidad. A raíz de estas consideraciones sería oportuno pensar en las posibilidades reales de creación de un sistema de comercialización online -distribución y visualización- del videoarte, productivo y razonable tanto para el espectador como para el artista e incluso para el resto de agentes y actores que intervienen en la comercialización del arte, tal y como realiza HAMACA. Media \& Video art distribution from Spain,

DOI: ri14.v12i2.707 | ISSN: 1697-8293 | Año 2014 Volumen 12 № 2 | ICONO14 
dedicada a la distribución de videoarte español, o UbuWeb, servicio independiente de obras audiovisuales underground y poesía de vanguardia, a través de las cuales se tiene acceso gratuito a la visualización parcial o íntegra de piezas audiovisuales en pantalla reducida.

La manejabilidad actual del medio permite un acceso más libre y un mayor rango de posibilidades de empleo, de lo cual se han sabido aprovechar los artistas. Además, el abaratamiento y popularización del vídeo a partir de su digitalización ha permitido un mayor grado de experimentación y accesibilidad, tanto en su producción como en su exhibición. Al mismo tiempo, los circuitos de distribución del videoarte contemporáneo han expandido sus posibilidades de visualización, ya sea por su divulgación a través de colecciones públicas o privadas o por facilitar el acceso a través de la web personal u otros canales de difusión de los propios videoartistas. Todo ello ofrece expectativas prometedoras para un futuro inmediato, aunque no exentas de riesgos y dificultades. Al igual que está sucediendo con todo tipo de creaciones videográficas, masivamente democratizadas por el abaratamiento y universalización de las tecnologías digitales y por la capacidad de difusión que ofrece Internet, la selección entre lo que realmente tiene un valor artístico y lo que no lo tiene se convierte en una tarea muy ardua, extenuante. Dejar esa tarea solo en manos de intereses mercantiles añade otros riesgos evidentes. Ceñirnos a clasificaciones artificiosas como las que acabamos de cuestionar, no parece arrojar mucha luz sobre la escena. Y no parece prudente ni justificado, por el momento, disolver el concepto de "videoarte" en otros conceptos más o menos asimilables, como el "Media Art". Estamos, pues, ante una reflexión abierta. Y para alimentarla, concluimos con una idea propuesta por Amber Gibson (2010, p. 21):

“Cualquier etiqueta es problemática, y las fronteras entre categorizaciones son cada vez más permeables, artificiales y menos precisas. Aunque hay quienes insisten en una definición del arte videográfico acorde con el medio, [...] usaré el termino videoarte de forma libre para referirme a cualquier obra con base en un contexto artístico (museo, galería, etc.) que consista en imágenes con un elemento temporal exhibidas en un espacio, independientemente de su soporte."

ICONO14 | Año 2014 Volumen 12 N² | ISSN: 1697-8293 | DOI: ri14.v12i2.707 


\section{Referencias}

Alcoz, Albert (2008). There is an experimental Cinema in Spain, but...

Experimental Conversations, $\mathrm{n}^{0} 2$ 2. Disponible en: http://www.

experimentalconversations.com/articles/169/there-is-an-experimental-

cinema-in-spain-but (Consultado el 10 de julio de 2014).

Baudrillard, Jean (1996). El crimen perfecto. Barcelona: Anagrama.

Bonet, Eugeni; Mercader, Antonio \& Muntadas, Antoni (1980). En torno al vídeo. Barcelona: Gustavo Gili.

Brea, José Luis (2000). Año Zero, Distancia Zero. En GUASCH, Anna María (Ed.). Los manifiestos del Arte Postmoderno. Textos de exposiciones, 1980-1995, Madrid: Akal, pp. 232-248.

Brea, José Luis (2005). Estudios visuales. La epistemología de la visualidad en la era de la globalización. Madrid: Akal.

Caballero Gálvez, Antonio A. (2012). La representación de la(s) masculinidad(es) en el videoarte español contemporáneo. Tesis doctoral (inédita).

De la Torre, Blanca \& Prieto, Inma (2011): “Ni son todos los que están, ni están todos los que son (Del lado de allá)" en el catálogo de la exposición Video(s) torias (Artium Centro-Museo Vasco de Arte Contemporáneo, Vitoria-Gasteiz), pp. 13-35.

Della Porta, Donatella \& Keating, Michael (Eds.) (2008): Approaches and Methodologies in the Social Sciences. Cambridge: Cambridge University Press.

Derrida, Jacques (1999). No escribo sin luz artificial. Valladolid: Cuatro.

Eco, Umberto (2004 [1965]). Apocalípticos e Integrados. Barcelona: Debolsillo.

Esteban de Mercado, Juan Carlos (2002). Vídeo-esculturas y vídeo-instalaciones en

España (Tesis doctoral, Universidad Complutense de Madrid). Disponible en: http://eprints.ucm.es/1849 (Consultado el 19 de marzo de 2014).

Expósito, Marcelo \& Villota, Gabriel (Eds.) (1993). Plusvalías de la imagen.

Anotaciones (locales) para una crítica de los usos (y abusos) de la imagen.

Bilbao: Sala Rekalde.

Gibson, Amber (2010). Algunos apuntes. EXIT Express, n 52, mayo 2010, pp. 1831.

Lizarazo Arias, Diego (2004): Iconos, Figuraciones, Sueños. Hermenéutica de las Imágenes. México D.F.: Siglo XXI.

DOI: ri14.v12i2.707 | ISSN: 1697-8293 | Año 2014 Volumen 12 N² | ICONO14 
Martín, Sylvia (2006). Videoarte. Madrid: Taschen.

Mirzoeff, Nicholas (2003). Una introducción a la cultura visual. Barcelona: Paidós. Mitchell, W. J. T. (2003). Mostrando el Ver: una crítica de la cultura visual.

Estudios Visuales, $\mathrm{n}^{0}$ 1, diciembre, pp. 17-40.

Moxey, Keith (2009). Los estudios visuales y el giro icónico. Estudios Visuales, $\mathrm{n}^{0}$ 6, enero, pp. 7-27.

Palacio, Manuel (Ed.) (1987). La imagen sublime. Vídeo de creación en España 1970-1987. Madrid: Centro de Arte Reina Sofía.

Quintana, Ángel (2011). Repensar las fronteras entre prácticas e imágenes.

Catálogo de la exposición Video(s)torias. Vitoria-Gasteiz: ARTIUM, CentroMuseo Vasco de Arte Contemporáneo, pp. 63-75.

Rekalde, Josu (2000). La creación audiovisual (vídeo). Euskonews \& Media, $\mathrm{n}^{0}$ 89. Disponible en: http://www.upv.es/laboluz/2222/textos/rekalde.htm (Consultado el 6 de junio de 2014).

Rush, Michael (2011). New media in art. Londres: Thames \& Hudson

Sichel, Berta (Ed.) (2003). Monocanal. Madrid: Museo Nacional Centro de Arte Reina Sofía.

Spielmann, Ivonne (2008). Video. The Reflexive Médium. Cambridge, Reino Unido: The MIT Press.

Zemos 98 (2006): La televisión no lo filma. Sevilla: Universidad Internacional de Andalucía; Instituto Andaluz de la juventud. Disponible en: http://www. zemos98.org/festivales/zemos988/pack/libro_LTVNLF.pdf (Consultado el 10 de julio de 2014)

Zunzunegui, Santos (1987). Espacio del sentido y escritura narrativa en el vídeo de creación. Telos, n 9, marzo-mayo, pp. 57-63.

VV.AA. (2009). 100 Videoartistas. Madrid: Exit Publicaciones.

\section{Catálogos}

Bienal de la Imagen en Movimiento '90. Comisario: José Ramón Pérez Ornia. Museo Nacional Centro de Arte Reina Sofía (MNCARS), Madrid, 1990. II Bienal de la Imagen en Movimiento. Visionarios Españoles. Comisaria: Carlota Álvarez Basso. Museo Nacional Centro de Arte Reina Sofía (MNCARS), Madrid, 1992.

ICONO14 | Año 2014 Volumen 12 Nº 2 | ISSN: 1697-8293 | DOI: ri14.v12i2.707 
D-Generados. Experiencias subterráneas de la no ficción española. Comisarios: Josetxo Cerdán y Antonio Weinrichter. Instituto Cervantes \& Las Palmas de Gran Canaria Internacional Film Festival, 2007.

Gustos, Colecciones y Cintas de vídeo. Comisaria: Virginia Torrente. Centro de Arte Dos de Mayo. Consejería de Cultura y Turismo, Comunidad de Madrid, Madrid, 2008.

Survideovisiones. Comisaria: Margarita Aizpuru. Programa INICIARTE, Consejería de Cultura, Junta de Andalucía, Sevilla, 2008.

XCÈNTRIC. 45 Películas contra dirección. Comisaria: Carolina López. Centre de Cultura Contemporània de Barcelona (CCCB) / Diputació de Barcelona, Barcelona, 2006. 